\title{
Estimation of coniferous standing tree volume using airborne LiDAR and passive optical remote sensing
}

\author{
Yohei NAKAI, Fumiki HOSOI, and Kenji OMASA \\ The University of Tokyo, Graduate School of Agricultural and Life Sciences
$1-1-1$ Yayoi, Bunkyo, Tokyo 113-8657, Japan
}

\begin{abstract}
In this study, we confirmed the utility of airborne LiDAR and passive optical remote sensing techniques for estimating the standing tree volume of two coniferous trees, 28 Japanese red pine and 13 Japanese cedar trees respectively. Airborne 3-D LiDAR data and aerial photographs provided the respective height and crown area for each of the selected trees. Subsequently, we examined the relationships between 1) LiDAR-derived tree height and Field-based stem volume and 2) the crown area obtained from aerial photograph and the field-based stem volume. In addition, we made a multiplicative equation composed of both tree height and crown area to predict the stem volume, and examined its accuracy by comparing the predicted standing tree volume with the field-based volume. Consequently, stronger correlations were observed between the LiDAR-derived tree height and stem volume in both species, while those between the crown area obtained from aerial photographs and the stem volume were weaker in both species. At the multiplicative equation, $R^{2}$ and $\mathrm{SE}$ of the stem volume were 0.90 and $0.046 \mathrm{~m}^{3}$ for the Japanese red pine, and 0.83 and $0.025 \mathrm{~m}^{3}$ for the Japanese cedar respectively, which represented a better result than using tree height or crown area alone, especially for the Japanese cedar. This shows the effectiveness of the combination of LiDAR and passive optical sensors in estimating the standing tree volume.
\end{abstract}

Key words: Airborne LiDAR, Japanese red pine, Passive optical remote sensing, Three-dimensional, Tree volume.

\section{Introduction}

Accurate estimation of tree volume is vital for conservation of the forest ecosystem and understanding of global climate change (Hobbs and Mooney, 1990; Omasa and Harasawa, 2003). Although field-based actual measurements reveal an accurate volume, their application is limited because they are very laborious or destructive (Husch et al., 1982; Nagumo and Minowa, 1990). Recently therefore, remote sensing techniques such as LiDAR and passive optical sensors have been developed as indirect methods capable of efficiently obtaining wide area information. They have also been applied when estimating forest resources such as tree volume and structural parameters (Nelson et al., 1988; Omasa et al., 2003, 2008; Næsset et al., 2004; Zheng et al., 2004; Urano and Omasa, 2005; Hosoi and Omasa,

Received; March 27, 2009.

Accepted; November 11, 2009.
2007; Takeda et al., 2008). However, their biomass estimation has been conducted on relatively limited tree species, and the methods remains insufficient for various species. With this in mind, there is a need to apply their biomass estimation method for other tree species and develop the estimation methods for the same. In addition, as measurement methods, the combination of LiDAR and passive optical sensors is considered effective.

In this study, we derived the structural parameters of the Japanese red pine (Pinus densiflora Siebold \& Zuccarini) from a combination of various remote sensing techniques, i.e. airborne LiDAR and passive optical remote sensing, and investigated the effectiveness of the parameters for standing tree volume estimation. Since there has been little study of efforts to estimate the standing tree volume of the Japanese red pine by the remote sensing based method to date, this species was selected in this study. In addition, to compare different 
tree species, a similar investigation was also conducted on the Japanese Cedar (Cryptomeria japonica [L. f.] D. Don).

\section{Materials and Methods}

\subsection{Study site}

The study was carried out in a mixed plantation in Ibaraki Prefecture, $40 \mathrm{~km}$ northeast of central Metropolitan Tokyo, Japan. The dominant tree species were the Japanese cedar (Cryptomeria japonica [L. f.] D. Don), Japanese red pine (Pinus densiflora Siebold \& Zuccarini), ginkgo (Ginkgo biloba Linnaeus), and Japanese zelkova (Zelkova serrata [Thunberg] Makino), and the undergrowth had been removed. From this site, 28 Japanese red pine and 13 Japanese cedar trees were selected for this experiment.

\subsection{Direct measurement of the tree height and DBH}

In December 2008, we measured the heights of the selected 28 Japanese red pine and 13 Japanese cedar trees on the ground using a range finder (Lasertape FG-21-HA, RIEGL, Austria) with an accuracy of \pm 5 $\mathrm{cm}$. Subsequently, we directly measured the Diameter at Breast Height (DBH) of each tree to calculate its volume. The girth of each tree was measured by survey taping and the DBH was obtained by dividing the length by $\pi$.

\subsection{Measurement using an airborne LiDAR sys- tem}

The study area was scanned in August 2005 by a LiDAR (ALTM 3100 DC, Optech Co.) mounted on a helicopter (Aero Asahi Co., Japan). The airborne LiDAR calculated the distance to a target via the time-of-flight method, and incorporated first- and last-pulse modes, in which the first and last returned laser pulses were detected. The crown surface data were received by first-pulse mode (FP-mode), so the data of FP-mode were selected to generate an image of the woody outer crown in the following process. The laser wavelength was $1,064 \mathrm{~nm}$, and its repetition frequency was $50,000 \mathrm{~Hz}$. The scanning frequency was set to $20 \mathrm{~Hz}$, and the density of the laser pulses was 13.3 pulses $\mathrm{m}^{-2}$. The scanning angle, range and horizontal accuracy were $20.0^{\circ}, \pm 15$ and $13 \mathrm{~cm}$, and the flight speed and height were $50 \mathrm{~km} / \mathrm{h}$ and $400 \mathrm{~m}$, respectively. Besides 3-D point cloud data, as data of passive optical remote sensing, aerial photographs of the area were also captured from $400 \mathrm{~m}$ above.

\subsection{Estimating the tree height from 3-D LiDAR data and the crown areas from aerial photo- graphs}

By triangulating and smoothing the FP-mode 3-D point cloud data, a polygonal 3D-LiDAR image of the woody crown within the study area was generated. In addition, a DTM (Digital Terrain Model) of the ground surface was generated by interpolating the extracted ground-level data from the LP-mode data. For the selected 28 Japanese red pine and 13 Japanese cedar trees, the heights were determined detecting the tops. In the aerial photograph, each of the selected tree canopies was segmented along their contours using a method based on the Watershed algorithm (Wang et al., 2004). Here, the slope of the crown was calculated from the intensity data of the aerial photograph and traced in each crown. The contours of the canopies were identified based on the inflection points of the slope. In this study, the area of each segment in each tree was named as the crown area and calculated by counting the corresponding number of pixels in each of the segments.

\subsection{Derivation of relationships between the field- based stem volume and parameters estimated from LiDAR data and aerial photograph}

The field-based volume of each tree stem was calculated from the directly measured DBH and the LiDAR-derived tree height using an allometric equation in each species (The Forestry Agency of Japan, 1970).

For both the Japanese cedar and Japanese red pine, we examined the relationships between i) LiDARderived tree heights and Field-based stem volume ii) crown areas obtained from aerial photographs and Field-based stem volume. In addition, based on the examination of the above two relationships, we made a multiplicative equation to predict stem volume using the dual parameters of crown area and tree height, as follows:

$$
V_{p}=a \times C A^{b} \times H^{c}
$$

Where $V_{p}$ represents the predicted tree stem volume, $C A$ the crown area obtained from aerial photographs, and $H$ the LiDAR-derived tree height. The coefficients of $a, b$ and $c$ were determined by applying multiple regression analysis.

\section{Results and Discussion}

Fig. 1 (B) shows the 3D-LiDAR image of part of the 

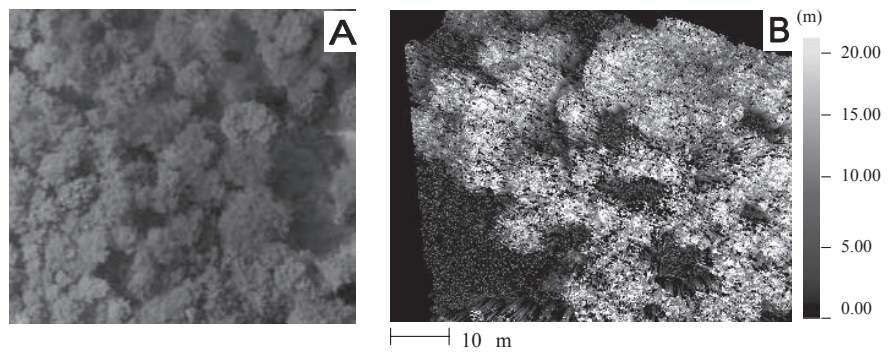

Fig. 1. The data of the measurement area obtained by airborne LiDAR and passive optical remote sensing. (A) Aerial photograph obtained by optical remote sensing. (B) 3D-LiDAR image generated from FP-mode 3D point cloud data.

study area generated from 3D point cloud data by the airborne LiDAR. The latter allowed the generation of precise 3-D visual models of the study area.

Fig. 2 shows the segmentation result in an aerial photograph based on the Watershed algorithm. Each crown is indicated as a black region, with the individual boundaries represented as white lines. By comparing the segmentation results with a tree position map obtained by ground truth measurement and an aerial photograph, it was confirmed that most tree canopies were well-segmented, although there were some over- or underestimated areas.

Fig. 3 shows the relationships between tree height estimated using airborne LiDAR and the field-based tree stem volume of (A) the Japanese red pine and (B) the Japanese cedar. They showed power functional relationships. The $R^{2}$ and Standard Error (SE) of stem volume for the Japanese red pine were respectively 0.90 and $0.042 \mathrm{~m}^{3}$, and 0.74 and $0.090 \mathrm{~m}^{3}$ for the Japanese cedar. Stronger correlations between the

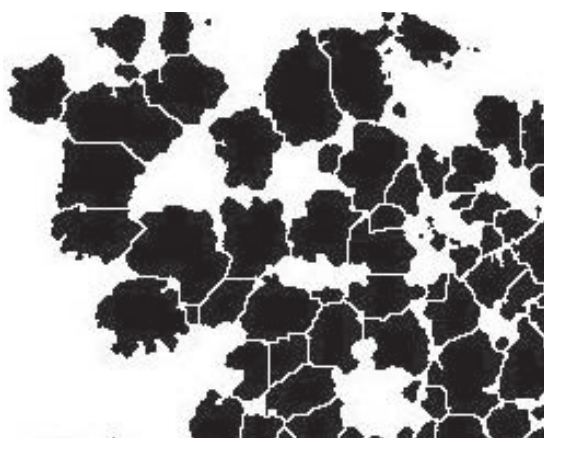

Fig. 2. The segmentation result in aerial photograph based on Watershed algorithm. Each crown is indicated as black region and the boundaries of each crown are represented as white lines.
LiDAR-derived tree height and stem volume were obtained for both species than those between the crown area and stem volume as described below.

Fig. 4 shows the relationships between the crown areas calculated by aerial photographs and the fieldbased tree stem volume of (A) the Japanese red pine and (B) the Japanese cedar. They also showed the power functional relationships. $R^{2}$ and SE of the stem volume for the Japanese red pine were respectively 0.61 and $0.096 \mathrm{~m}^{3}$, and 0.35 and $0.097 \mathrm{~m}^{3}$ for the Japanese cedar. In both species, correlations between the crown areas and tree stem volumes were worse than the cases in Fig. 3. It was also observed that the crown areas of Japanese red pine varied more widely than the Japanese cedar.

Coefficients $a, b$ and $c$ in Eq. (1) were respectively $10^{-4.89}, 0.16$ and 3.78 , for the Japanese red pine and respectively $10^{-5.19}, 1.19$ and 3.19 for the Japanese cedar. Fig. 5 shows comparisons of the stem volume between the predicted and field-based values of (A) the Japanese red pine and (B) the Japanese cedar. The $R^{2}$ and SE of the stem volume were 0.90 and $0.046 \mathrm{~m}^{3}$ for the Japanese red pine, and 0.83 and $0.025 \mathrm{~m}^{3}$ for the Japanese cedar. Regarding the values of $R^{2}$ and $\mathrm{SE}$, it was shown that stem volume can be predicted more accurately from Eq. (1) composed of both tree height and crown area as compared with using the tree height or crown area alone, especially for the Japanese cedar.

It emerged in Fig. 3 that the LiDAR-derived tree height alone allowed an accurate estimation of stem volume. For details, some errors were observed at a height exceeding $13 \mathrm{~m}$ in Fig. 3, where the regression curves steepened. Because of the steep curve, a few errors of LiDAR-derived tree height would have caused the errors of estimation for the stem volume, 

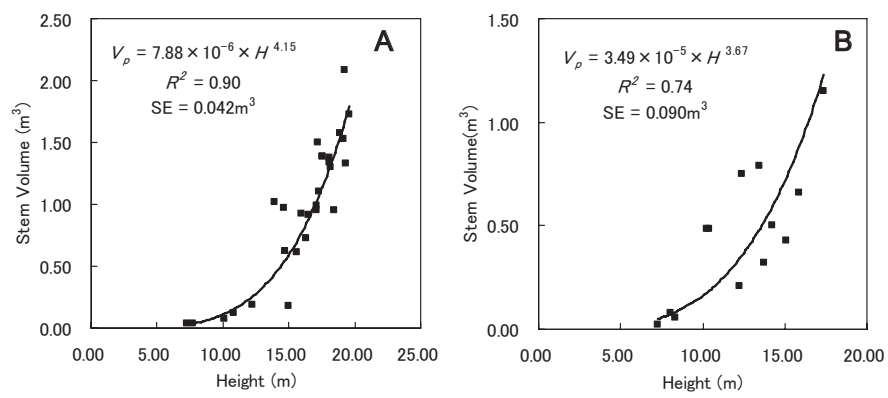

Fig. 3. Relationships between the tree height estimated using airborne LiDAR and the field based tree stem volume. (A) Japanese red pine (B) Japanese cedar. Where $V_{p}$ is predicted tree stem volume, and $H$ is LiDARderived tree height.
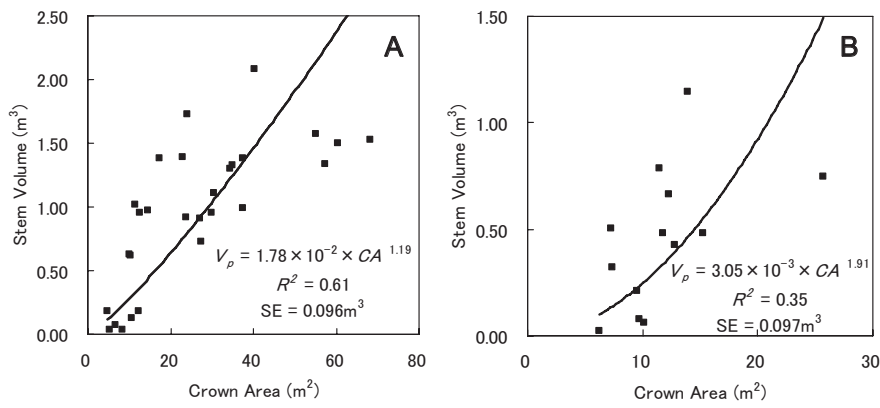

Fig. 4. Relationships between the crown area calculated by the aerial photograph and the field based tree stem volume. (A) Japanese red pine (B) Japanese cedar. Where $V_{p}$ is predicted tree stem volume, and $C A$ is crown area obtained from aerial photograph.
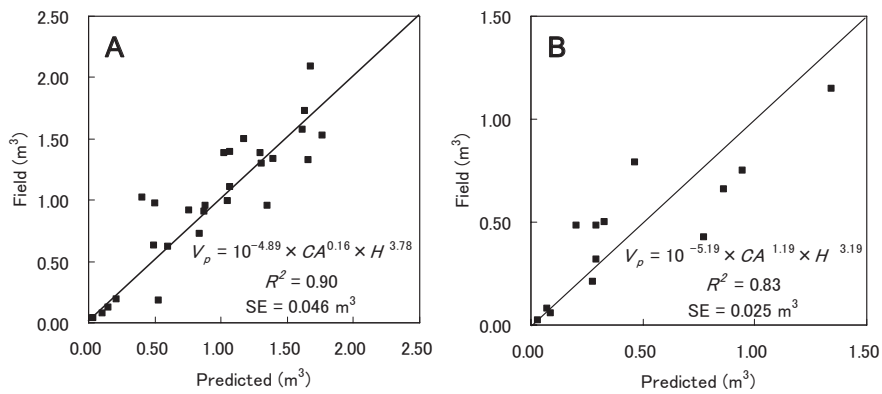

Fig. 5. Comparisons of stem volume between the predicted values using LiDAR-derived tree height and crown area obtained from an aerial photograph, and field-based values. (A) Japanese red pine (B) Japanese cedar

while some actual measurement errors would be also included in the field-based stem volume, i.e. errors of range finding for tree height measurements and those of survey taping for DBH measurements.

In this study, the crown area was chosen as a parameter to represent the horizontal structure of the crown and it appeared useable for the stem volume estimation. However, even if trees have the same stem volume, the values of the crown area may differ depending on the 3-D structure, e.g. in terms of blanching pattern or foliage distribution, which would explain the poor correlation between the crown areas and the tree stem volume. Consequently, it seems difficult to estimate stem volume accurately from crown 
area alone. In terms of species difference, the crown area of the Japanese red pine varied more widely than the Japanese cedar, suggesting the former has more structural variability than the latter.

Multiple regression analysis revealed the t-values of the tree height and crown area at 9.02 and 1.10 for the Japanese red pine, and 6.00 and 2.97 for the Japanese cedar respectively. The t-value of tree height exceeded that of the crown area for each species, so it seems that the element of tree height affects the stem volume more heavily than the crown area.

It can be concluded that the proposed multiplicative equation composed of tree height from 3-D LiDAR data and crown areas from aerial photography is better for estimating the stem volume of the present two coniferous trees than using the tree height or crown area alone, which shows the effectiveness of the combination of LiDAR and passive optical sensors for standing tree volume estimation. In future, more works should be conducted for more species to exploit the findings of the present study.

\section{References}

Hobbs, R. J., and Mooney, H. A. (ed.), 1990: Remote sensing of biosphere functioning. Springer-Verlag, $312 \mathrm{pp}$.

Hosoi, F., and Omasa, K., 2007: Factors contributing to accuracy in the estimation of the woody canopy leaf-area-density profile using 3D portable lidar imaging. J. Exp. Bot., 58, 3464-3473.

Husch, B., Miller, C. I., and Beers, T. W., 1982: Forest mensuration. J. Wiley, New York, 402 pp.

Nagumo, H., and Minowa, M., 1990: Study of tree measurement. Chikyu-sha, Tokyo, 243 pp. (in Japanese).

Nelson, R., Krabill, W., and Tonelli, J., 1988: Estimating forest biomass and volume using airborne laser data. Remote Sens. Environ., 24, 246-267.

Næsset, E., Gobakken, T., Holmgren, J., Hyyppä, H.,
Hyypää, J., Maltamo, M., Nilsson, M., Olsson, H., Persson, Å., and Söderman, U., 2004: Laser scanning of forest resources: the Nordic experience. Scand. J. For. Res., 19, 482-499.

Omasa, K., and Harasawa, H. (ed.), 2003: Global warming. Trend of the recent studies and technical solutions. Biological science. Inheritance. Special edition 17. Syoukabou, Tokyo, 172 pp. (in Japanese).

Omasa, K., Hosoi, F., Uenishi, T. M., Shimizu, Y., and Akiyama, Y., 2008: Three-dimensional modeling of an urban park and trees by combined airborne and portable on-ground scanning LIDAR remote sensing. Environ. Model. Assess., 13, 473-481.

Omasa, K., Qiu, G. Y., Watanuki, K., Yoshimi, K., and Akiyama, Y., 2003: Accurate estimating of forest carbon stocks by 3-D remote sensing of individual trees. Environ. Sci. Technol., 37, 1198-1201.

Takeda, T., Oguma, H., Sano, T., Yone, Y., Yamagata, Y., and Fujinuma, Y., 2008: Estimating the plant area density of a Japanese larch (Larix kaempferi Sarg.) plantation using a ground-based laser scanner. Agric. For. Meteorol., 148, 428-438.

The Forestry Agency of Japan, 1970: Timber Volume Table-East Japan. Nihon Ringyo Chousakai, Tokyo, 333 pp. (in Japanese).

Urano, Y., and Omasa, K., 2005: Estimation of tree stem diameters and biomass in Japanese cedar forest using portable imaging lidar data. J. Agric. Meteorol., 60, 1175-1177.

Wang, L., Gong, P., and Biging, G. S., 2004: Individual tree-crown delineation and treetop detection highspatial-resolution aerial imagery. Photogramm. Eng. Remote Sens., 70, 351-357.

Zheng, D. L., Rademacher, J., Chen, J. Q., Crow. T., Bresee. M., Le Moine, J., and Ryu, S. R., 2004: Estimating aboveground biomass using Landsat 7 ETM + data across a managed landscape in northern Wisconsin, USA. Remote Sens. Environ., 93, 402-411. 


\title{
航空機搭載型 LiDAR および受動型光学りモート センシングを用いた針葉樹の材積量推定
}

\author{
中井洋平・細井文樹・大政謙次 \\ (東京大学農学生命科学研究科)
}

要

本研究では, 2 種の針葉樹, 28 本のアカマツと 13 本 のスギの立木材積推定における航空機搭載型 LiDAR と受動型光学リモートセンシング技術の有用性を確証し た。航空機からの 3-D LiDAR データと航空写真によつ て対象樹それぞれの樹高と樹冠面積が得られた。その 後，1) LiDAR から得た樹高と野外調查幹体積，2) 航 空写真から得た樹冠面積と野外調查幹体積との関係を 分析した。それに加えて, 幹体積を推定するために樹高 と樹冠面積を用いた乗法式を作成し，推定した幹体積 と野外調查幹体積とを比較することで精度の検証を行っ た。結果として, 両種共に航空写真から得られた樹冠面
約

積と幹体積との相関関係は他より劣つたものの, LiDAR 由来の樹高と幹体積との間には良い相関関係が見られ た。乗法式においては, アカマッでは $R^{2}=0.90, \mathrm{SE}=$ $0.046 \mathrm{~m}^{3}$, スギでは $R^{2}=0.83, \mathrm{SE}=0.025 \mathrm{~m}^{3}$ となり, 特にスギにおいて樹高や樹冠面積を単独使用した際より も良い結果となった。これは LiDAR と受動型光学セン サーとの組み合わせは立木材積推定において効果的であ ることを示している。

キーワード：アカマツ, 航空機搭載型 LiDAR, 3 次元, 受動型光学リモートセンシング, 立木材積 